\title{
Digital Skills in Mexican Children
}

\author{
Carlos Arturo Torres Gastelú ${ }^{1}$ \\ ${ }^{1}$ University of Veracruz, Mexico
}

\begin{abstract}
Nowadays the children of the primary public schools in Mexico face the challenge of a balanced development of digital competencies. The purpose of this document is to show the preliminary results of a study that analyzes the ITC knowledge and skills of students in the primary education for the municipalities of Veracruz, Boca del Rio and Medellin. A descriptive study was realized by a quantitative methodology. The results indicate that the students possesses major skill in the Internet use that in the basic managing of the TIC.
\end{abstract}

Keywords: ITC, Primary Education, Competencies, Mexico, Digital Divide.

\section{Digital Skills in Students}

In average, the students of basic education were born twelve years ago. Commonly referred to as Digital Natives (Prensky 2001a), the Net Generation (Tapscott 1998), the Millennial Generation (Howe and Strauss 2000) and Generation M (Roberts et al. 2005), these individuals are said to have been "born digital" (Palfrey and Gasser 2008) into the early twenty-first century. They are native speakers of the digital age. These students don't have to translate or learn ICT, but merely experience it (Nasah, Dacosta, Kinsell \& Seok, 2010).

Many researchers have disagreed with what has been called an overly simplified characterization of an entire generation. They have further contended that our understanding of students' use of ICT is far from clear (Bennett et al. 2008). In fact, there is mounting evidence that the actual uses of ICT by students are much more limited in scope than the rhetoric implies (Selwyn 2009). According to Lohnes and Kinzer (2007), recent studies suggest that students do not expect or want to use ICT in educational settings in the same way they do at home or in the community. Actually, there is little evidence that students want more ICT integration in the classroom (McWilliam 2002). According to Keen (2007) and Torres (2011), students are much more interested in using ICT for social-networking purposes than for learning.

In addition to these findings, there is research suggesting that students' use of ICT may be influenced by a number of factors. For example, the 2005 Kaiser Family Foundation Study (Roberts et al. 2005) showed that use of technology had dramatically increased since a prior 1999 study. Among other findings, the study reported that, typically, 8 - to 18 year olds are exposed to $8.5 \mathrm{~h}$ of recreational media per day. While alarming, the authors warned that these numbers vary in relation to demographic characteristics, such as parents' level of education, family income level and ethnic background. Similarly, Downes (2002), for example, indicated that the nature of students' home computer use is influenced by family dynamics and domestic affluence. Further, both Kennedy et al. (2008) and Kvavik et al. (2004) found differences in ICT use related to socioeconomic status, cultural/ethnic background, gender and discipline specialization. Finally, Livingstone and Bober (2004) noted that the nature 
and frequency of students' Internet use differ based on age and socioeconomic status. This is in line with Salaway et al. (2008), who found similar results with age, in that it was the single most important factor with regard to the usage and perception of social networking activities.

Finally, empirical findings show that students' use of ICT is driven by factors such as age, socioeconomic status, living arrangement and locale (Kennedy et al. 2008). Thus, their use of ICT may be more a matter of digital literacy and digital access than a generational trait.

In this sense, it is relevant to study how is the perception of the students about their Internet skills and also basic use of Information and Communication Technology (ICT) in order to evaluate how deep is the integration of this technologies for this Digital Natives.

\section{Methodology.}

A descriptive study was realized by a quantitative methodology. The population was constituted by the students of the sixth grade of the primary public schools in three municipalities (Veracruz, Boca del Rio and Medellin) in the state of Veracruz, Mexico. The sample was integrated by 1,229 students of 41 schools (Table 1).

The sample was shaped by 651 women $(53 \%)$ and 578 men (47\%). The average age of the students was 12 years old, with a minimum of 10 and maximum of 17.

Table 1. Students distribution by municipality and gender

\begin{tabular}{|l|c|c|}
\hline Municipality & Female & Male \\
\hline Veracruz & $54.2 \%$ & $51.2 \%$ \\
\hline Boca del Rio & $24.6 \%$ & $25.8 \%$ \\
\hline Medellin & $21.2 \%$ & $23 \%$ \\
\hline Total & $100 \%$ & $100 \%$ \\
\hline
\end{tabular}

The quantitative instrument referring to the ITC and Internet Basic Knowledge was integrated by 13 questions that should be answered using a scale of type Likert (I don't know what is / I don't know what it means; I know what is it, but I don't know how to do it; I can do it if someone help; I can do it by myself).

\section{Results}

The table 2 shows the percentages obtained for each one of the items that shape to the dimension knowledge about ITC and Internet.

Table 2. ITC and Internet Basic Knowledge of Students in Primary Education.

\begin{tabular}{|l|c|c|c|c|}
\hline \multicolumn{1}{|c|}{ Category } & $\mathrm{A}$ & $\mathrm{B}$ & $\mathrm{C}$ & $\mathrm{D}$ \\
\cline { 2 - 5 } & $\%$ & $\%$ & $\%$ & $\%$ \\
\hline Open a file & 6 & 10.3 & 26.7 & 57 \\
\hline Print a document & 3.7 & 11.8 & 30.8 & 53.7 \\
\hline $\begin{array}{l}\text { Install / Uninstall a } \\
\text { program }\end{array}$ & 12.4 & 21.5 & 35.3 & 30.8 \\
\hline $\begin{array}{l}\text { Create a text docu- } \\
\text { ment }\end{array}$ & 17.8 & 11.1 & 24.2 & 46.9 \\
\hline Creation of slides & 21.4 & 16.0 & 32.4 & 30.2 \\
\hline $\begin{array}{l}\text { Create a spread- } \\
\text { sheet }\end{array}$ & 23.4 & 19.4 & 34.3 & 22.9 \\
\hline Create a data base & 26.5 & 17.6 & 34.1 & 21.8 \\
\hline $\begin{array}{l}\text { Use a Internet } \\
\text { search engine to } \\
\text { look for information }\end{array}$ & 6.3 & 5.7 & 13 & 75 \\
\hline $\begin{array}{l}\text { Download a file } \\
\text { from Internet }\end{array}$ & 5.5 & 12.2 & 24.7 & 57.6 \\
\hline Send a E-mail & 4.1 & 12.9 & 17.4 & 65.6 \\
\hline $\begin{array}{l}\text { Use an instant mes- } \\
\text { sage program }\end{array}$ & 11.6 & 12.0 & 24.8 & 51.6 \\
\hline $\begin{array}{l}\text { Publish content on } \\
\text { Internet }\end{array}$ & 12.4 & 19.4 & 31.5 & 36.7 \\
\hline $\begin{array}{l}\text { Design or modify } \\
\text { Web pages or blogs }\end{array}$ & 18.1 & 27.3 & 33.3 & 21.3 \\
\hline
\end{tabular}

Nomenclature: (A) I don't know what is / I don't know what it means; (B) I know what is it, but I don't know how to do it; (C) I can do it if someone help; (D) I can do it by myself.

The results of the table 2 indicate that the most developed students skills are concentrated in aspects related to the Internet use. 
Also the evidences denote that there does not exist a high domain of the technological tools in the students, however, in order to analyze this situation it is adopted the criterion for assuming that more developed skill and less developed skill exist in each of the items.

The level of development of the student skill is considered from the sum of the values obtained: "I can do it if someone help"; and also "I can do it by myself". On the basis of it is possible to establish three levels: Developed skills (from 80 to $99 \%$ ), Moderately well developed skills (from 60 to $79 \%$ ), and Less Developed skills (from 40 to $59 \%$ ).

In this sense, only a few categories can be considered developed in the students skills those related with Internet use (Internet search engine to look for information $88 \%$, Send a E-mail $83 \%$, Download a file $82.3 \%$ ); while in the ITC basic skills of the students only appears the categories: Open a file $(83.7 \%)$ and Print a document $(84.5 \%)$.

On the other hand, for the moderately well developed skills ranged from $62.6 \%$ to $76.4 \%$. Regarding Internet Basic Knowledge were found Instant messaging (76.4\%) and Publication of content in the Internet $(68.2 \%)$. While in ITC Basic Knowledge were found: Creation of a text document (71.1\%); Installation of a software $(66.1 \%)$ and the creation of slides $(62.6 \%)$.

Finally, the less developed skills were: Create a spreadsheet (57.2); Create a Database $(55.9 \%)$; and Design or modify Web pages or Blogs $(54.6 \%)$. The first two skills belongs to ITC Basic Knowledge category and the last one belongs to Internet Basic Knowledge category.

In order to detect if significant differences exist in the variable of genre, the $U$ of Mann-Whitner (U M-W) test was applied. The results showed in the Table 3 indicate that there is not significant differences. Nevertheless the found varia- tions prove to be unfavorable for the girls in the majority of the items.

Table 3. Differences by Genre

\begin{tabular}{|l|c|}
\hline Global Mean & 2.71 \\
\hline Women Mean & 2.7 \\
\hline Men Mean & 2.71 \\
\hline U of M-W & 184387 \\
\hline Z & -0.605 \\
\hline Sig. (Bilateral ) & 0.545 \\
\hline T & -1 \\
\hline
\end{tabular}

Note: Confidence interval $(\mathrm{CI}=0.95)$

In table 4 appears the valuations emitted by the students of three municipalities, it is possible to observe that the municipality with the highest average is Boca del Rio (2.74) and the lowest is Veracruz (2.69). The statistician of contrast calculated in the ANOVA test provides the value $\mathrm{F}=3.4$, significant to 0.05 , with which the fact discards that the averages are equal in the three municipalities.

Tabla 4. Differences by Municipality

\begin{tabular}{|l|c|}
\hline Global Mean & 2.71 \\
\hline Mean of Veracruz (V) & 2.69 \\
\hline Mean of Boca del Río (B) & 2.74 \\
\hline Mean of Medellin (M) & 2.71 \\
\hline F & 3.4 \\
\hline $\begin{array}{l}\text { The differences are pro- } \\
\text { duced between }\end{array}$ & V-B \\
\hline
\end{tabular}

\section{Conclusions}

The students skills in the Internet use need to be improved, but specially basic skills of Information and Communication Technology. There were not significant differences in the genre variable. Nevertheless, there were differences in the results obtained in two of three municipalities. 


\section{References}

[1] Bennett, S., Maton, K., \& Kervin, L. (2008). The 'digital natives' debate: A critical review of the evidence. British Journal of Educational Technology, 39(5), 775-786.

[2] Downes, T. (2002). Blending play, practice and performance: Children's use of the computer at home. Journal of Educational Enquiry, 3(2), 21-34.

[3] Howe, N., \& Strauss, W. (2000). Millennials rising: The next great generation. New York: Vintage Books.

[4] Keen, A. (2007). The cult of the amateur: How today's Internet is killing our culture. London: Broadway Business.

[5] Kennedy, G., Krause, K.-L., Judd, T., Churchward, A., \& Gray, K. (2008). First year students' experiences with technology: Are they really digital natives? Australasian Journal of Educational Technology, 24(1), 108-122.

[6] Kvavik, R. (2005). Convenience, communications, and control: How students use technology. In D. G. Oblinger \& J. L. Oblinger (Eds.), Educating the net generation (Chap. 7). Boulder, CO: EDUCAUSE.

[7] Livingstone, S., \& Bober, M. (2004). Taking up online opportunities? Children's use of the Internet for education, communication and participation. E-Learning, 1(3), 395-419.

[8] Lohnes, S., \& Kinzer, C. (2007). Questioning assumptions about students' expectations for technology in college classrooms. Innovate, 3 . Retrieved September 15, 2011 from http://innovateonline.info/index.php? view $=$ article \&id $=431 \&$ action $=$ article.

[9] McWilliam, E. L. (2002). Against professional development. Educational Philosophy and Theory, 34(3), 289-300.

[10] Nasah, A.; Dacosta, B. Kinsell; \& Seok, S. (2010). The digital literacy debate: an investigation of digital propensity and information and communication technology. Education Tech Research Dev (2010) 58:531-555. DOI $10.1007 / \mathrm{s} 11423$ 010-9151-8.

[11] Palfrey, J., \& Gasser, U. (2008). Born digital: Understanding the first generation of digital natives. New York: Basic Books.

[12] Prensky, M. (2001a). Digital natives, digital immigrants. On the Horizon, 9, 1-6. Retrieved January 16, 2012 from

http://www.marcprensky.com/writin g/default.asp.

[13] Roberts, D. F., Foehr, U. G., \& Rideout, V. (2005). Generation M: Media in the lives of 8-18 year-olds, pp. 1-145. Retrieved March 29, 2009 from http://www.kff.org/entmedia/upload/ Generation-M-Mediain-the-Livesof-8-18-Year-olds-Report.pdf.

[14] Salaway, G., Caruso, J. B., Nelson, M. R., \& Ellison, N. (2008). The ECAR study of undergraduate students and information technology, 2008, 8. Retrieved June 24, 2009 from

http://net.educause.edu/ir/library/pdf /ERS0808/RS/ERS0808w.pdf.

[15] Selwyn, N. (2009). The digital native - myth and reality. Paper presented at the CILIP (Chartered Institute of Library and Information Professionals) London seminar series. http://www.scribd.com/doc/9775892 /Digital-Native.

[16] Tapscott, D. (1998). Growing up digital: The rise of the net generation. New York: McGraw-Hill Companies.

[17] Torres, C. (2011). Uso de las TIC en un programa educativo de la Universidad Veracruzana, México. Revista Actualidades Investigativas en Educación. Vol. 11, Número Especial pp. 1-22. 